DOI: $10.4274 /$ tjps. 46547

\title{
SIMULTANEOUS ESTIMATION OF SAXAGLIPTIN AND DAPAGLIFLOZIN IN HUMAN PLASMA BY VALIDATED HPLC-UV METHOD
}

Saxagliptin ve dapagliflozin tarafindandoğrulanmiş HPLC-UV yöntemiinsanplazmaeşzamanlitahmin

\section{ESTIMATION OF SAXAGLIPTIN AND DAPAGLIFLOZIN IN HUMAN PLASMA}

SAXAGLIPTIN ve DAPAGLIFLOZIN insanplazmatahmin

$$
\text { Sharmila Donepudi }{ }^{1} \text {, SuneethaAchanta }{ }^{2 *}
$$

${ }^{1}$ Department of PharmaceuticalAnalysis, V.V. Institute of Pharmaceutical Sciences, Andhra Pradesh, India.

2Department of Pharmaceutical Analysis, Hindu College of Pharmacy, Andhra Pradesh, India

*Correspondance:

A. Suneetha.

Department of Pharmaceutical Analysis,

Hindu College of Pharmacy,

Amaravathi Road, Guntur-522 002

Andhra Pradesh, India.

E-mail:drasuneetha@gmail.com 


\begin{abstract}
:
Objective: The fixed dose combination of saxagliptin and dapagliflozin, recently approved antidiabetic medication. It is marketed with a brand name Qtern. The intend method aim to develop a simple, rapid, sensitive and validated isocratic reversed phase high performance liquid chromatography (RP-HPLC) method for the simultaneous estimation of saxagliptin and dapagliflozin in human plasma by using linagliptin as internal standard as per US-FDA guidelines.
\end{abstract}

Materials and methods: The method was performed on Waters 2695 HPLC equipped with quaternary pump. The analyte separation was achieved using Eclipse XDB C18 $(150 \times 4.6 \mu \times 5 \mathrm{~mm})$ column with a mobile phase consisting of $0.1 \%$ ortho phosphoric acid and acetonitrile (50:50) with $\mathrm{pH}$ adjusted to 5.0 at $1 \mathrm{ml} / \mathrm{min}$ flow rate.

Results: The analyte was detected at $254 \mathrm{~nm}$. Retention time of the internal standard, saxagliptin and dapagliflozin was found at 2.746, 5.173 and 7.218minutes, respectively. The peaks were found to be free of interference. The method is validated over a dynamic linear range of 0.01 to $0.5 \mu \mathrm{g} / \mathrm{ml}$ and 0.05 to $2 \mu \mathrm{g} / \mathrm{ml}$ for saxagliptin and dapagliflozin, respectively, with a correlation coefficient of 0.998 . The precision and accuracy of samples of six replicate measurements at LLOQ level was within limit. The analytes were found to be stable in human plasma at $-28^{\circ} \mathrm{C}$ for 37 days.

Conclusion: The stability, sensitivity, specificity and reproducibility of this method make it appropriate for the determination of saxagliptin and dapagliflozin in human plasma.

Key words: Saxagliptin, Dapagliflozin, Linagliptin, Human plasma, Isocratic.

Özet:

Amaç: Saxagliptin ve dapagliflozin'in sabit doz kombinasyonu antidiyabetik ilaç tedavisi için onaylanmıştır ve Qtern markası ile pazarda yer almaktadır.Bu çalışmada amaç, insan plazmasındaki Saxagliptin ve dapagliflozin'in eş zamanlı tayini için US-FDA klavuzlarına uygun şekilde linagliptin iç standardı kullanarak ve basit, hızlı, hassas ve validasyonu yapılmış izokroatik ters faz yüksek performanslı sıvı kromatografi (RPHPLC) yöntemi geliştirmektir. 
Gereç ve Yöntem: Method 4'lü akış pompasına sahip Waters 2695 marka HPLC cihazı ile gerçekleştirilmiştir. Analitin ayrılmasında Eclipse XDB C18 kolon (150 X 4.6 $\mu \mathrm{m}$ X $5 \mathrm{~mm}$ ) kullanılmıştır. Kullanılan mobil fazın bileşimi ise $\mathrm{pH} 5.0^{\prime}$ e ayarlanmış \%0.1 orto fosforik asit ve asetonitril (50:50) şeklinde olup akış hızı analiz süresince $1 \mathrm{ml} / \mathrm{dk}$ 'dır. Bulgular: Analit 254nm'de tayin edilmiştir. İç standart, saxagliptin ve dapagliflozin'in alıkonma zamanları sırasıyla 2.746, 5.173 ve $7.218 \mathrm{dk}$ olarak tespit edilmiştir. Pikler interferanslar gözlenmeden elde edilmiştir. Metot validasyonu saxagliptin ve dapagliflozin için sırasıyla 0.01 ile $0.5 \mu \mathrm{g} / \mathrm{ml}$ ve 0.05 ile $2 \mu \mathrm{g} / \mathrm{ml}$ doğrusal derişim aralığında 0.998 korelasyon katsayısı ile gerçekleştirilmiştir. Numunlere ait 6 ölçüme ait kesinlik ve doğruluk tayin sınırları içerisinde bulunmuştur. Analitlerin insan plazması içinde $-28^{\circ} \mathrm{C}$ sıcaklıkta 37 gün boyunca kararlı halde kaldığı belirlenmiştir

Sonuç: Bu yönteme ait elde edilen kararlılık, duyarlıık, özgüllük ve tekrarlanabilirlik sonuçları, geliştirilen bu yöntemin insan plazmasında saxagliptin ve dapagliflozin'in belirlenmesi için uygun olduğunu ortaya koymuştur.

Anahtarkelimeler: Saxagliptin, Dapagliflozin, Linagliptin, Insanplazma, Isocratic. 


\section{INTRODUCTION}

The combination of saxagliptin and dapagliflozin has the potential to confer significant benefits in glycaemic control without the risk of weight gain and hypoglycaemia, which may be associated with other medications used to treat type 2 diabetes(1). The fixed dose combination containing $10 \mathrm{mg}$ dapagliflozin and $5 \mathrm{mg}$ saxagliptin was recently approved by the FDA for adults with type- 2 diabetes. The combination was available with a brand name Qtern(2). Dapagliflozin belongs to the sodium glucose cotransporter-2 (SGLT2) inhibitors with a chemical name (2S,3R,4R,5S,6R)-2-[4-chloro-3(4-ethoxybenzyl)phenyl]-6-(hydroxymethyl) tetrahydro-2/H-pyran-3,4,5-triol (fig.1a)(3-6).

Saxagliptin belongs to the class of drugs inhibiting the enzyme dipeptidyl-peptidase-4 (DPP-4). This class of compound works by stimulating glucose-dependent insulin release. Chemically, it is (1S,3S,5S)-2-((2S)-Amino(3-hydroxytricyclo(3.3.1.13,7)dec-1yl)acetyl)-2-azabicyclo(3.1.0) hexane-3-carbonitrile (fig .1b) and with a molecular formula $\mathrm{C}_{18} \mathrm{H}_{25} \mathrm{~N}_{3} \mathrm{O}_{2}$ (7-9). A review of the literature revealed that a few analytical methods like LC-MS(10-11), HPLC (12-19), and spectroscopic methods(20-21) are available for the estimation of these drugs, either indlividually or in combination with other diabetic drugs like metformin(22-26). The present work aimedto develop a simple, rapid and accurate method for the estimation of dapagliflozin and saxagliptin in human plasma, as per USFDA guidelines (27). Also, the present method is the first for the estimation of this combination in a biological matrix.

\section{MATERIALS AND METHODS}

\section{Reagents and chemicals}

The pure drug samples of saxagliptin and dapagliflozin were purchased from Selleckchem.com LLC, supplied by Pro lab marketing. HPLC grade acetonitrile, HPLC grade methanol and all other chemicals were obtained from Merck Chemical Division, Mumbai. HPLC grade water obtained from the Milli-Q water purification system was used throughout the study. 


\section{Instrumentation}

Chromatography was performed with Waters 2695 HPLC provided with a quaternary pump, auto-sampler, column oven, degasser and \& 2996 PDA detector to provide a compact and with class Empower-2 software.

\section{Chromatographic conditions}

The separation was achieved by isocratic elution using an Eclipse XDB C18 column $(150 \times 4.6 \mu \mathrm{m} \times 5 \mathrm{~mm})$ with a mobile phase consisting of $0.1 \%$ orthophosphoric acid and acetonitrile (50:50) with a $\mathrm{pH}$ adjusted to 4.5 . The separation was achieved within $10 \mathrm{~min}$ at $254 \mathrm{~nm}$ using $1 \mathrm{ml} / \mathrm{min}$ flow rate. The sample dilution was carried by using a water:acetonitrile (50:50) ratio as a diluent.

\section{Preparation of internal standard}

The working standard of internal standard was prepared by transferring $10 \mathrm{mg}$ of linagliptin to $a 10 \mathrm{ml}$ volumetric flask; the final volume was completed using the diluent. From the resulting stock, $10 \mu \mathrm{g} / \mathrm{ml}$ solution was prepared by further dilutions.

\section{Preparation of calibration and quality control solutions}

The stock solutions of saxagliptin and dapagliflozin were prepared individually by dissolving $10 \mathrm{mg}$ of the drug in $10 \mathrm{ml}$ of diluent to obtain a $1 \mathrm{mg} / \mathrm{ml}$ concentration of each analyte. The stock solution was further diluted to prepare working standards. The calibration and quality control samples were obtained by spiking $10 \mu$ l of the aboveprepared solutions of each analyte into $250 \mu \mathrm{L}$ of plasma containing $50 \mu \mathrm{L}$ of the internal standard. This resulted in final concentrations of saxagliptin and dapagliflozin of $0.01 \mu \mathrm{g} / \mathrm{mL}$ to $0.50 \mu \mathrm{g} / \mathrm{mL}$ and $0.05 \mu \mathrm{g} / \mathrm{mL}$ to $2.00 \mu \mathrm{g} / \mathrm{mL}$, respectively, after spiking them into the plasma.

\section{Sample preparation and extraction}

The standard plasma samples, containing $10 \mu \mathrm{l}$ of each analyte and $50 \mu \mathrm{l}$ of internal 
standard $(10 \mu \mathrm{g} / \mathrm{mL})$, were mixed with $2 \mathrm{~mL}$ of acetonitrile. The sample tubes were vortexed for $2 \mathrm{~min}$. and were then centrifuged at $3200 \mathrm{rpm}$ for $3 \mathrm{~min}$. The resultant organic layer was used for analysis. The resultant organic layer was used for analysis.

\section{Method validation}

A thorough and complete method validation was performed following the USFDA guidelines. The method was validated for system suitability, auto-sampler carryover, specificity and screening of the biological matrix, sensitivity, matrix effect, linearity, precision and accuracy, recovery of the analyte and internal standard, ruggedness, reinjection reproducibility and stability. The stability studies include bench top, freezethaw and long-term stability at $-28^{\circ} \mathrm{C}$ and $-80^{\circ} \mathrm{C}$.

\section{Specificity}

Specificity of the biological matrix was assessed and screening was performed using six blank standards and lower limit of quàntification (LLOQ) level samples. All of the samples were checked to determine the extent of interference by the plasma components with the analyte and internal standard.

\section{Calibration curve}

The linearity of the method was determined by analysis of the standard plots associated with an eight-point standard calibration curve. Eight concentrations of saxagliptin and dapagliflozin range from 0.01 to $0.50 \mu \mathrm{g} / \mathrm{ml}$ and 0.05 to $2.00 \mu \mathrm{g} / \mathrm{ml}$, respectively, were used, which included the LLOQ, LQC, MQC, HQC and ULOQ. The calibration curve was constructed by plotting the peak area ratio of the analytes to the internal standard against standard concentrations. The percentage difference of back-calculated concentrations to the nominal concentration (distribution of the residuals) was determined to validate the correlation. The acceptance criteria for the calibration model applied if residuals were within 15\% for all calibration levels except LLOQ. Correlation coefficient, slope and intercept were determined to evaluate the calibration curve.

\section{Accuracy and Precision}


Intra-day precision and accuracy were assessed at the lower, middle, high and lower limit of quantification quality control samples LQC, MQC, HQC and LLOQ in six replicates for both of the analytes, while inter-day precision and accuracy were assessed for three consecutive days by using quality control samples.Mean values were obtained for calculated drug concentration over these batches. The accuracy of the analytical method describes the closeness of the mean test results obtained by the method to the actual value of the analyte and was determined by replicate analysis of the analyte. The accuracy and precision were calculated and expressed in terms of $\%$ mean accuracy and coefficient of variation (\% CV), respectively.

\section{Recovery}

Recovery of the analytes from the extraction procedure was performed at LQC, MQC, and HQC levels. It was assessed by comparing the peak area of the extracted samples (spiked before extraction) to the peak area of the unextracted samples (quality control working solutions spiked in extracted plasma).

\section{Ruggedness}

Ruggedness refers to the ability of an analytical method to remain unaffected by small variations. Parameters were used to evaluate the constancy of the results when external factors such as analyst, laboratory, instrument, reagents and days are varied. The ruggedness of the method assessed was determined using different analysts and on different instruments of the same make.

\section{Sensitivity}

Sensitivity is defined as the lowest analyte concentration that can be measured with acceptable accuracy and precision. Sensitivity experiments were carried out by using six replicates of the LLOQ level sample to determine the lowest limit of detection, the \% mean accuracy and the $\%$ coefficient of variation.

\section{Stability}


Stability studies were performed by keeping replicates of plasma samples at room temperature for $24 \mathrm{hrs}$. The freeze-thaw stability of the drugs in plasma samples were studied over three freeze-thaw cycles, by thawing at room temperature for 2-3 $\mathrm{h}$ and refrozen for 12-24 $\mathrm{h}$. The stability of the drugs in plasma was also tested after storage at $-80^{\circ} \mathrm{C}$. The concentration of the drugs after each storage period was related to the initial analyte concentrations of freshly prepared samples. Samples were considered stable if the assay values were within the acceptable limits of accuracy and precision.

\section{RESULTS}

\section{Method optimisation}

To obtain the best results, different mobile phase compositions containing phosphate buffer systems with varied $\mathrm{pH}$ and organic solvents like methanol and acetonitrile were used to provide adequate sensitivity and selectivity in a short separation time. The best results were obtained with the mobile phase consisting of $0.1 \%$ phosphoric acid $(\mathrm{pH}$ $4.5)$ and acetonitrile (50:50) with a flow rate of $1 \mathrm{mi} / \mathrm{min}$. The detection was monitored at $254 \mathrm{~nm}$. With these conditions, the retention times of linagliptin, saxagliptin and dapagliflozin were found to be $2.784,5.295$ and 7.204 minutes, respectively.

\section{Method validation}

\section{System suitability and auto-sampler carry over}

System suitability was assessed by using the MQC level sample as six homogenous injections. The \%coefficient of variation for retention time and response was calculated. The results were presented in table 1 . The obtained values are lower than $1 \%$, which shows the suitability of the system for the analysis of the selected combination in human plasma.

Auto-sample carryover was assessed by ULOQ (upper limit of quantification) and LLOQ levels to ensure that it did not affect the accuracy and precision. There was no carryover observed.

\section{Linearity}


The ratio of peak area of analyte to internal standard was used for construction of the calibration curve. The linearity of saxagliptin and dapagliflozin was established by an eight-point calibration curve. The most variable regression equation of the calibration curve for saxagliptin and dapagliflozin was $y=0.126( \pm 0.02) x+0.003 \& y=0.53( \pm 0.02) x-$ 0.002 , respectively. The linearity of the calibration graph was validated by the high value of the correlation coefficient with an average value of 0.996 and 0.998 for saxagliptin and dapagliflozin, respectively. The standard curves of saxagliptin and dapagliflozin are presented in fig. 2.

\section{Precision \& Accuracy}

The precision and accuracy of the methods were assessed by analysing six replicates of LLOQ, LQC, MQC and HQC levels. The accuracy of the method was determined by calculating the $\%$ mean accuracy and the precision by calculating relative standard deviation (RSD). The data regarding precision and accuracy are summarised in table 2. The chromatogram of quality control samples is shown in fig. 3 . The \% mean accuracy of saxagliptin and dapagliflozin ranged from 98.33 to 101.29 and from 98.43 to 103.28 , respectively.

\section{Recovery}

Recovery of saxagliptin and dapagliflozin was determined by comparing the mean peak areas of six replicates of three quality control samples (HQC, MQC \& LQC) with the mean peak areas of unextracted quality control samples at the same level. The results of the recovery study are given in table3. The results are within the acceptance limits.

\section{Rugged/ness}

The present method showed good ruggedness when the method was performed using different analysts and on different instruments of the same make. The results of the ruggedness study were found to be within acceptable limits, proving no significant analyst-to-analyst and instrument-to-instrument variation and hence the ruggedness of the method. The results are presented in table 4 .

\section{Stability}


The stability of the analytes in human plasma was assessed by the analysis of six replicates of quality control samples at low and high concentration levels at room temperature over 24 hours (bench top stability). The measured concentrations were compared with those of freshly prepared and processed samples. The results obtained indicated that the two drugs saxagliptin and dapagliflozin were stable for at least 24 hours in human plasma when retained at room temperature. On the other hand, the results obtained for quality control samples subjected to long-term stability at $-28^{\circ} \mathrm{C}$ for 37 days and at $-80^{\circ} \mathrm{C}$ indicate the stability of analytes in human plasma. In contrast, the freeze-thaw stability determined by using LLOQ, LQC, MQC and HQC level of samples also indicated the stability of analytes in human plasma. The results obtained are compiled in table 5 .

\section{DISCUSSION}

Since there is no reported sensitive method for the estimation of saxagliptin and dapagliflozin as a combination, the validated LC-UV method was developed for routine analysis in a biological matrix. Moreover, the available methods were developed to assess drugs either individually or in combination. Therefore, there is a need to develop an analytical method for the estimation of this combination. The current method aims to develop a simple, accurate and reliable method for the simultaneous estimation of saxagliptin and dapagliflozin in human plasma. Good resolution and minimum tailing was achieved by using this method. The method used a simple single step protein precipitation with acetonitrile and provided good selectivity when tested for peak interference from endogenous sources by comparing the blank chromatogram with quality control samples. The retention times of the internal standard, saxagliptin and dapagliflozin were found to be $2.746,5.173$ and 7.218 minutes, respectively. The developed method proved to be rugged and had adequate recovery and no matrix effect. The recovery was determined by comparing the extracted sample with the unextracted samples at three quality control sample levels i.e., LQC, MQC, LLOQ. The results were found to be within acceptable limits. The linearity of the method was tested by developing an eight-point calibration curve which included all quality control sample concentrations. The linear range for saxagliptin and dapagliflozin was found to be 0.01 
to $0.50 \mu \mathrm{g} / \mathrm{ml}$ and 0.05 to $2.00 \mu \mathrm{g} / \mathrm{ml}$, respectively. The regression coefficient and equation for saxagliptin and dapagliflozin was 0.996 and 0.998 , respectively. The linear range and statistical parameters prove that the developed method is more sensitive than the reported liquid chromatography coupled with a PDA detector. Using the stability studies, it was found that analytes were stable in plasma throughout the analysis period. The stability data were built by comparing the stability samples with freshly prepared samples. On the other hand, long-term stability was established by subjecting quality control samples to $-28^{\circ} \mathrm{C}$ for 37 days and to $-80^{\circ} \mathrm{C}$. The results obtained indicate that the method is sensitive, reliable and a cost-effective method. Furthermore, the method can be made applicable for pharmacokinetic estimation.

\section{CONCLUSION}

The proposed method for the estimation of a saxagliptin and dapagliflozin binary mixture in human plasma is simple, accurate and reliable. The single-step protein precipitation, short runtime of 10 minutes and isocratic elution make the method economical and suitable for the analysis of a large number of samples. The method has been validated as per the requirements of the US-FDA. It can therefore be concluded that the method is suitable for the routine quantification of saxagliptin and dapagliflozin in human plasma.

\section{Acknowledgement:}

The authors are thankful for V.V. Institute of Pharmaceutical Sciences, Gudlavalleru for providing facilities to carry out this work.

\section{Referenc}

1. Williams DM \& Stephens JW. Combination Therapy with Saxagliptin and Dapagliflozin for the Treatment of Type 2 diabetes. Expert Opin on Pharmacother, 2015; 16(15): 2373-2379.

2. FDA Approves Once-Daily Qtern (dapagliflozin and saxagliptin) Tablets for Adults with Type-2 Diabetes [Internet]. Drugs.com. Available from: https://www.drugs.com/newdrugs/fda-approves-once-daily-qtern-dapagliflozinsaxagliptin-adults-type-2-diabetes-4493.html. 
3. Manasa S, Dhanalakshmi K, Nagarjunareddy G \& Sreenivasa S. Development and Validation of a RP-HPLC Method for the Estimation of Dapagliflozin in API. Int J Pharm Sci, 2014; 5(12): 5394-5397.

4. Shyamala M, Nidhi B, Kavitha M, Pooja \& Sharma JV. Validated RP-HPLC Method for Simultaneous Estimation of Metformin Hydrochloride and Dapagliflozin in Tablet Dosage Form. AJBPR, 2015;2(2):109-113.

5. Dapagliflozin [Internet]. National Center for Biotechnology Information. PubChem Compound Database. U.S. National Library of Medicine; Available from: https://pubchem.ncbi.nlm.nih.gov/compound/Dapagliflozin(accessed May 23, 2017).

6. DaveDJ, Saxagliptin: A dipeptidyl peptidase-4 inhibitor in the treatment of type 2 diabetes mellitus. J Pharmacol Pharmacother. 2011 Oct-Dec; 2(4):230-235.

7. Saxagliptin [Internet]. National Center for Biotechnology Information. PubChem Compound Database; U.S. National Library of Medicine; Available from:https://pubchem.ncbi.nlm.nih.gov/compound/Saxaglitin (accessed May 23, 2017).

8. Gumieniczek A, \&Berecka A. Analytical tools for determination of new oral antidiabetic drugs, glitazones, gliptins, gliflozins and glinides, in bulk materials, pharmaceuticals and biological samples. Open Chem, 2016; 14(1):215-242.

9. El-Bagary RI, Elkady EF, \&Ayoub BM. Spectrophotometric Methods Based on Charge Transfer Complexation Reactions for the Determination of Saxagliptin in Bulk and Pharmaceutical Preparation. Int J Biomed Sci, 2012; 8(3): 204-208.

10. Aubry A, G H, Magnier R, Morgan L, Xu X, Tirmenstein, et.al.,. Validated LCMS/MS Methods for the Determination of Dapagliflozin, a Sodium-Glucose CoTransporter 2Inhibitor in Normal and ZDF Rat Plasma. Bioanalysis, 2010; 2(12):2001-2009.

11. Batta N, Pilli N, Derangula V, Vurimindi H, Damaramadugu R\&Yejella R. A Rapid and Sensitive LC-MS/MS Assay for the Determination of Saxagliptin and its Active Metabolite 5-Hydroxy Saxagliptin in Human Plasma and its application to a pharmacokinetic study. Drug Res. 2014; 65(03):133-140. 
12. Pawanjeet JC, Balaji M, Srinivasarao V, Ramakrishna K\&Apparao KM. Devolpment and validation of simple stability indicating RP-HPLC method for analysis of saxagliptin and its forced degradation impurities in bulk drug and pharmaceutical dosage form. Int J Res Dev Pharm L Sci, 2014, 3(3), 993-1003.

13. Scheeren LE, Marcolino AIP, Adams AIH\&Rolim CMB. Stability indicating RPLC-PDA method for the quantitative analysis of saxagliptin in pharmaceutical dosage form. Braz J Pharm Sci, 2015; 51(2), 461-466.

14. Md. Saiful Islam, Md. Taleb Hossain, Sukalyan Kumar Kundu, Md. Abdul Halim\&Md. Rafiquzzaman. Development and validation of RP-HPLC method for determination of saxagliptin hydrochloride in bulk and tablet dosage form. World Journal of Pharmaceutical Research, 2016; 5(5), 107-119.

15. Daswadkar SC, Roy MA, Walode SG \&Mahendra Kumar CB. Quality by design approach for the development and validation of saxagliptin by RP-HPLC with application to formulated forms. Int J Pharm Sci, 2016; Vol. 7(4): 1670-1677.

16.SenaCaglar\& Ali Rahmi Alp. A Validated HighPerformance Liquid Chromatography Method for the Determination of Saxagliptin and Metformin in Bulk, a Stability Indicating Study. J Anal Bioanal Tech. 2014; S12,1-5.

17. Sanagapati M, Dhanalakshmi K, Nagarjunareddy G \&Sreenivasa S. Development and validation of a RP-HPLC method for the estimation of dapagliflozin in API. Int J Pharm Sci, 2014; Vol. 5(12): 5394-5397.

18. Debata J, Kumar S, Jha SK\&Khan A. A New RP-HPLC method development and validation of dapagliflozin in bulk and tablet dosage form. Int J Drug Dev \& Res. 2017;9: 48-51.

19. Jeyabaskaran M, Rambabu C \&Dhanalakshmi B. RP-HPLC method development and validation of dapagliflozin in bulk and tablet formulation, IJPAR, 2013; 2(4):221-226.

20. Kalaichelvi R \& Jayachandran E. Validated spectroscopic method for estimation of saxagliptin in pure and from tablet formulation. IntJ Pharm Pharm Sci, 2011;3(3):179-180.

21.8. Moneeb SM. Spectrophotometric and spectrofluorimetric methods for the determination of saxagliptin and vildagliptin in bulk and pharmaceutical 
preparations. Bulletin of Faculty of Pharmacy, Cairo University (2013) 51, 139_ 150.

22. Prasad PBN, Satyanaryana K \& Krishnamohan G. Development and Validation of a Method for Simultaneous Determination of Metformin and Saxagliptin in a Formulation by RP-HPLC. Am J of Anal Chem.2015; 6, 841-850.

23. Merey $\mathrm{HA}$ et al., Chromatographic methods for the simultaneous determination of binary mixture of Saxagliptin $\mathrm{HCl}$ and Metformin $\mathrm{HCl}$, Bulletin Facult Pharmacy Cairo Univ (2017), http://d.doi.org/10.1016/j.bfopcu.2017.04.002.

24. Thangabalan B, Srisowmya P \& Manohar Babu S. Method development and validation for simultaneous estimation of saxagliptin and metformin in tablet dosage form by RP-HPLC method. IJPAR, 2014; 3(4): 363-369.

25. Mohammad Yunoos and Gowri Sankar D. Stability indicating quantitative RPHPLC method development and validation for simultaneous determination of metformin hydrochloride and saxagliptin in bulk and combined tablet dosage form. J Chem Pharm Res., 2015, 7(4):346-355.

26. Mohammad Yunoos\&Gowrisankar D. A validated stability indicating highperformance liquid chromatographic method for simultaneous determination of metformin hcl and dapagliflozin in bulk drug and tablet dosage form. Asian $\mathrm{J}$ Pharm Clin Res, 2015; 8(3): 320-326.

27. Guidance for Industry. Bioanalytical Method Validation for human studies. U. S. Department of Health and Human Services Food and Drug Administration, Center for Drug Evaluation and Research (CDER); 2013. p. 1-23. 
Table 1: Statistical analysis of system suitability parameters

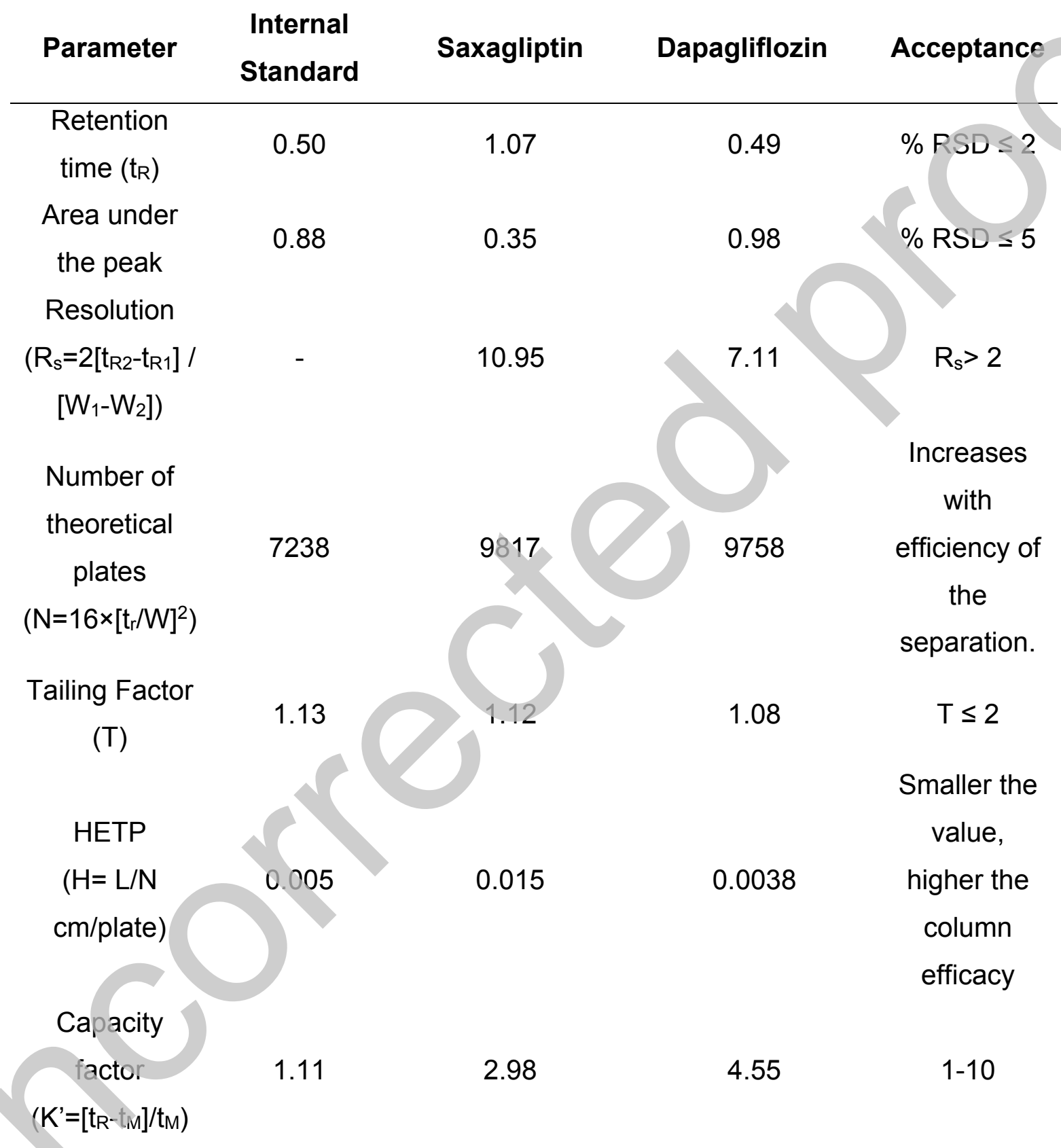


Table2: Intra and inter day precision and accuracy summary ${ }^{*} n=18$ Added conc. Saxagliptin Dapagliflozin

\begin{tabular}{|c|c|c|c|c|c|c|c|c|}
\hline \multirow{2}{*}{$(\mu \mathrm{g} / \mathrm{ml})$} & & & & & & \\
\hline & 0.40 & 0.02 & 0.040 & 0.010 & 1.60 & 1.00 & 0.2 & 0.050 \\
\hline \multicolumn{9}{|c|}{ Between-batch (n=18) } \\
\hline Mean & 0.4038 & 0.0199 & 0.0394 & 0.0098 & 1.6127 & 1.0017 & 0.2019 & 0.0496 \\
\hline SD & 0.0196 & 0.0015 & 0.0021 & 0.0008 & 0.0743 & 0.0763 & 0.0103 & 0.0037 \\
\hline \%RSD & 4.85 & 7.29 & 5.31 & 7.99 & 4.61 & 7.62 & 5.12 & 6.97 \\
\hline$\% \mathrm{CV}$ & 100.94 & 99.44 & 98.61 & 98.33 & 100.79 & 100.17 & 100.95 & 99.26 \\
\hline \multicolumn{9}{|c|}{ Day $1(n=6)$} \\
\hline Mean & 0.4030 & 0.0197 & 0.0395 & 0.0098 & 1.6128 & 1.0085 & 0.2018 & 0.0493 \\
\hline SD & 0.0217 & 0.0012 & 0.0016 & 0.0008 & 0.1138 & 0.0915 & 0.0097 & 0.0037 \\
\hline \%RSD & 5.40 & 6.16 & 4.16 & 7.66 & 7.05 & 9.08 & 4.83 & 7.44 \\
\hline$\% \mathrm{CV}$ & 100.75 & 98.33 & 98.75 & 98.33 & 100.80 & 100.85 & 100.92 & 98.67 \\
\hline \multicolumn{9}{|c|}{ Day $2(n=6)$} \\
\hline Mean & 0.4052 & 0.0200 & 0.0395 & 0.0098 & 1.6117 & 1.0328 & 0.2062 & 0.0492 \\
\hline SD & 0.0107 & 0.0017 & 0.0027 & 0.0008 & 0.0534 & 0.0525 & 0.0114 & 0.0029 \\
\hline$\%$ RSD & 2.65 & & & 7.66 & 3.31 & 5.08 & 5.52 & 5.90 \\
\hline$\% \mathrm{CV}$ & & 100.00 & 98.75 & 98.33 & 100.73 & 103.28 & 103.10 & 98.43 \\
\hline \multicolumn{9}{|c|}{ Day $3(n=6)$} \\
\hline Mean & 0.4032 & 0.0200 & 0.0393 & 0.0098 & 1.6135 & 0.9637 & 0.1977 & 0.0503 \\
\hline so & 0.0267 & 0.0017 & 0.0022 & 0.0010 & 0.0545 & 0.0755 & 0.0098 & 0.0042 \\
\hline$\%$ RSD & 6.61 & 8.37 & 5.49 & 10.00 & 3.38 & 7.83 & 4.94 & 8.40 \\
\hline$\% C V$ & 100.79 & 100.00 & 98.33 & 98.33 & 100.84 & 96.37 & 98.83 & 100.67 \\
\hline
\end{tabular}


Table 3: Extraction recovery data from human plasma * $n=6$ Nominal

\begin{tabular}{cccc} 
Analyte & $\begin{array}{c}\text { concentration } \\
(\boldsymbol{\mu} \mathbf{g} / \mathrm{ml})\end{array}$ & \% Recovery & \% RSD* \\
& $0.04(\mathrm{LQC})$ & 76.40 & 1.58 \\
\hline \multirow{2}{*}{ Saxagliptin } & $0.20(\mathrm{MQC})$ & 88.07 & 0.21 \\
& $0.4(\mathrm{HQC})$ & 71.60 & 2.08 \\
& Across mean & 78.689 & 8.469 \\
& $0.2(\mathrm{LQC})$ & 82.82 & 0.17 \\
Dapagliflozin & $1.0(\mathrm{MQC})$ & 78.76 & 0.93 \\
& $1.6(\mathrm{HQC})$ & 82.79 & 0.96 \\
& Across mean & 81.458 & 2.86 \\
Internal standard & 0.1 & 82.22 & 0.46 \\
\hline
\end{tabular}


Table-4: Ruggedness data * $n=6$

Parameter

Saxagliptin

Dapagliflozin

$\begin{array}{lllllll}\text { HQC } & \text { MQC } & \text { LQC } & \text { LLOQ HQC } & \text { MQC } & \text { LQC } & \text { LLOQ }\end{array}$

\section{Different Column}

$\begin{array}{lllllllll}\text { Mean } & 0.401 & 0.195 & 0.039 & 0.010 & 1.597 & 1.008 & 0.198 & 0.050\end{array}$

$\begin{array}{lllllllll}\text { SD } & 0.027 & 0.011 & 0.001 & 0.008 & 0.119 & 0.052 & 0.011 & 0.004\end{array}$

$\begin{array}{lllllllll}\% \text { CV } & 6.66 & 5.38 & 2.98 & 7.66 & 7.47 & 5.12 & 5.31 & 7.90\end{array}$

$\begin{array}{ccccccccc}\text { \% Mean } & 100.1 & 97.50 & 97.92 & 98.33 & 99.79 & 100.77 & 98.83 & 100.00\end{array}$ Accracy 7

\section{Different Analyst}

$\begin{array}{lllllllll}\text { Mean } & 0.404 & 0.195 & 0.040 & 0.010 & 1.614 & 1.006 & 0.201 & 0.049\end{array}$

$\begin{array}{lllllllll}\text { SD } & 0.018 & 0.0164 & 0.002 & 0.001 & 0.070 & 0.071 & 0.009 & 0.002\end{array}$

$\begin{array}{lllllllll}\text { \% CV } & 4.39 & 8.43 & 3.84 & 8.94 & 4.35 & 7.02 & 4.45 & 4.71\end{array}$

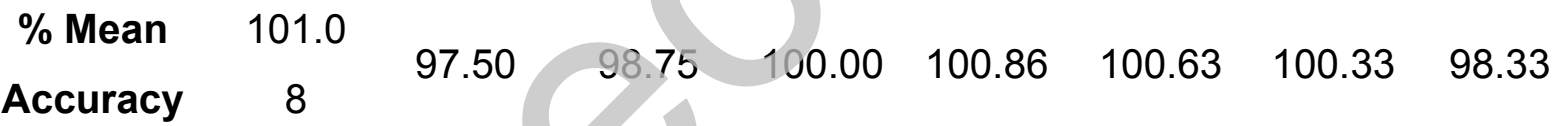


Table5: Stability data of saxagliptin and dapagliflozin in human plasma

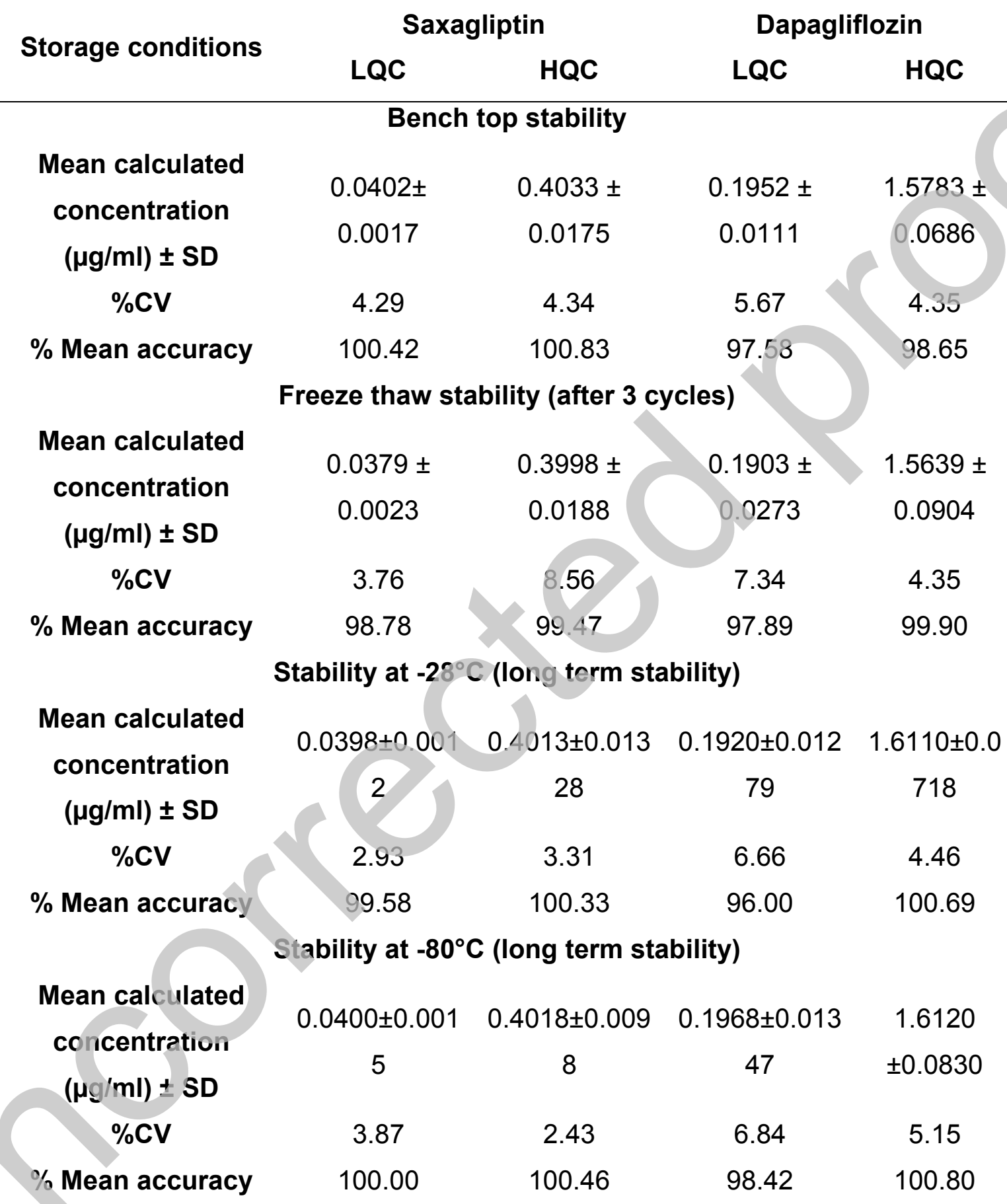




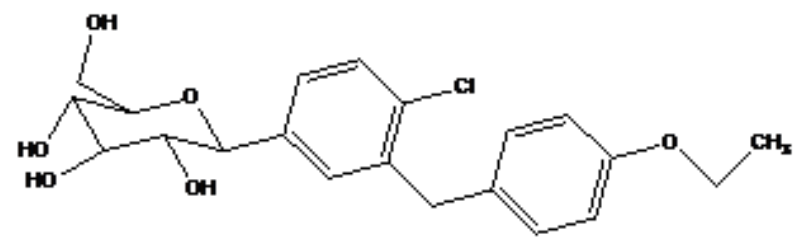

(a)

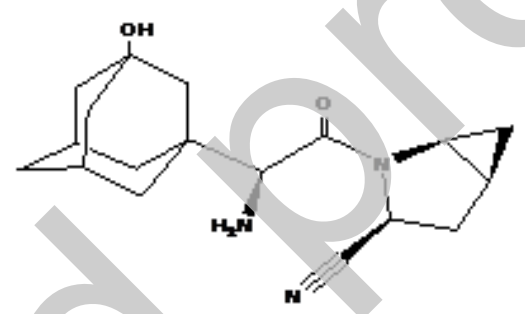

(b)

Fig. 1: Chemical structure of dapagliflozin (a) and saxagliptin (b). 

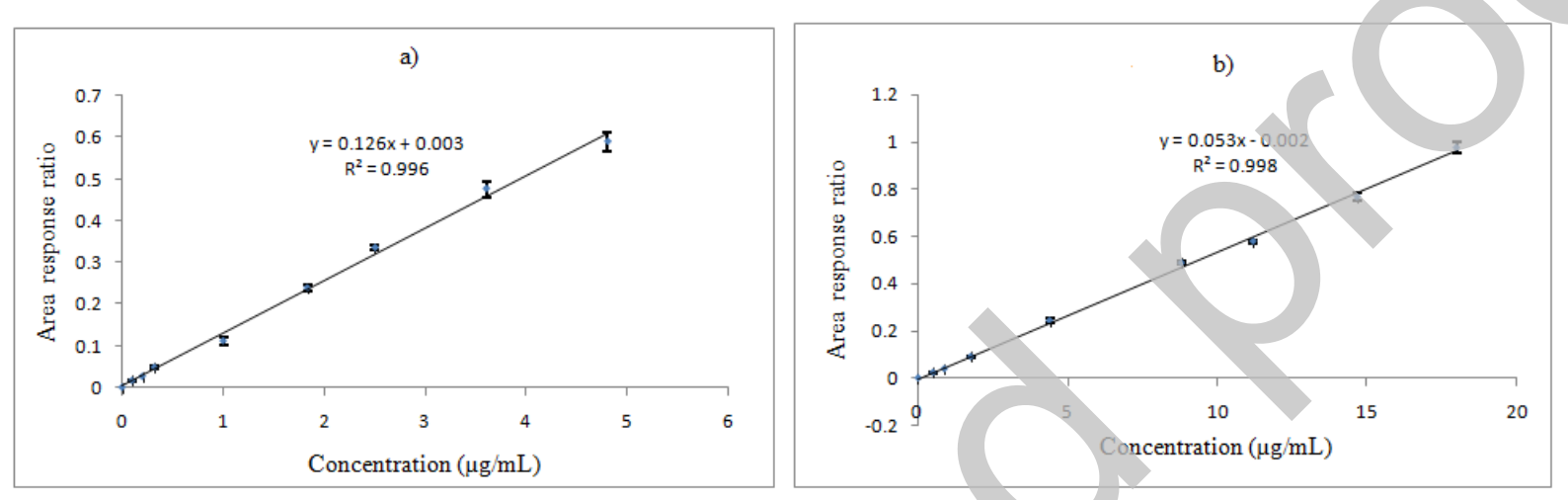

Fig. 2: Standard curves of saxagliptin (a) and dapagliflozin (b). 

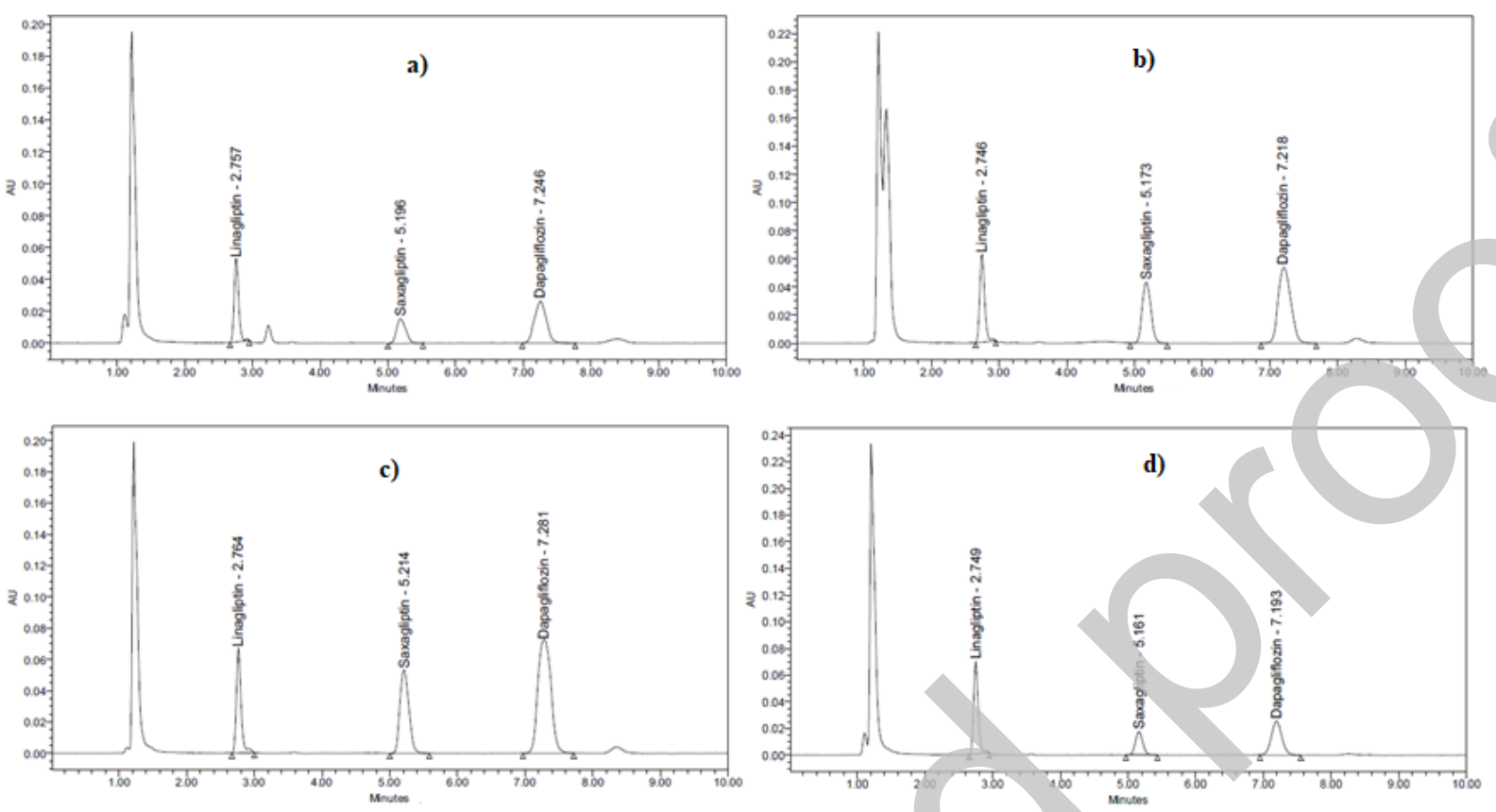

Fig. 3: Chromatograms of Low QC Sample(a), Middle QC Sample (b), High QC Sample (c) and Lower Limit QC sample (d). 